\title{
Interest in Currency Trading Learning - Preferred Methods and Motivational Factors
}

\author{
Rok Pintar ${ }^{1}$, Eva Jereb ${ }^{1}$, Mladen Čudanov², Marko Urh ${ }^{1}$ \\ ${ }^{1}$ University of Maribor, Faculty of Organizational Sciences, Kidričeva cesta 55a, 4000 Kranj, Slovenia \\ rok.pintar@fov.uni-mb.si, eva.jereb@fov.uni-mb.si, marko.urh@fov.uni-mb.si \\ ${ }^{2}$ University of Belgrade, Faculty of Organizational Sciences, Jove llića 154, 11000 Belgrade, Serbia \\ mladenc@fon.bg.ac.rs
}

Background and purpose: This paper analyzes the interest of potential users for learning in the field of currency trading or foreign exchange (forex, FX). The purpose of our article is a) to present currency trading, b) to present different options, methods and learning approaches to educating in forex, c) to present the research results discovering the interest of potential users for learning in the field of currency trading.

Methodology: For gathering data, an online questionnaire was used. It was distributed so that the survey sample covers socio-demographic variables (gender, age, working status, relationship status, financial status of credit and educational level). Interest in learning in the field of currency trading was assessed. Descriptive statistics, t-test, paired samples test, homogeny test of variances, and ANOVA were used.

Results: It was determined that people are interested in learning about currency trading, especially younger ones $(<30$ years), who prefer e-learning as their learning approach. Obtaining and possessing the right information is the strongest motivation factor and fearing not having enough necessary prior knowledge is the strongest discouraging factor for learning about currency trading.

Conclusion: Education of users in the field of currency trading is becoming increasingly popular with the development of e-learning.

Keywords: currency trading, forex, e-learning

\section{Introduction}

Currency trading is a very popular and new form of investing of financial resources, which is inherently different from traditional methods of investing. Therefore, high potential for education in the field of currency trading exists. With the development of information and communication technology, the forex market is expanding rapidly, and constant learning in the currency trading field is essential.

\section{Literature review}

Since the beginning of floating exchange rates, trading has become widespread in the currency trading (forex) markets, and academic investigations of this field have largely been limited to daily data (Dempster, Payne, Romahi \& Thompson, 2001). This currently remains valid because we are limited to daily recognition of currency market when researching the interest in learning about forex. Loginov and

Received: $11^{\text {th }}$ September 2015; revised: $20^{\text {th }}$ October 2015; accepted; $20^{\text {th }}$ December, 2015 
Heywood (2013) think that currency trading is not just for educated and experienced investors, but also for all who can consider their investment options and are motivated to participate in the forex market. Being the largest financial market in the world, the foreign exchange market significantly affects employment and inflation, thus rightly draws much attention from researchers (Lallouache \& Abergel, 2014). Everyone has a chance to evolve as a trader, practice his skills, develop instincts, and plan tactics in currency trading. Therefore, there is no guaranteed formula for success in currency trading even if people are constantly learning and are a part of all known methods and learning approaches in forex.

The currency market (foreign exchange market, forex, FX) is used for the trading of different currencies. In the forex market, trading is done by selling and buying currency pairs (Talebi, Winsor \& Gavrilova, 2014). An international forex market is assumed, in which traders (regardless of nationality) can freely trade domestic and foreign currencies (Proano, 2011). Currency trading is available to every individual who has access to the platform and knows how to use it. According to Talebi, Winsor and Gavrilova (2014), the currency market is the largest trading market in the world. The foreign exchange market is also one of the most liquid markets in the world (Evans, Pappas \& Xhafa, 2013). The forex market is organized as a decentralized multiple dealership market (Høidal Bjønnes and Rime, 2005), which consists of currency spot, forwards, futures, options, and swap markets (Kumar, 2014). Unlike other financial markets, the forex market has neither a physical location nor a central exchange and it operates through a complex electronic network of banks, corporations, and individuals trading one currency for another (Amiri, Zandieh, Vahdani, Soltani \& Roshanaei, 2010). In currency trading, it is necessary to consider all of the latest information available, especially considering that each individual can obtain the desired information very quickly and practically anywhere and anytime in a relatively easy manner with the help of modern technology (Chau, Deesomak \& Lau, 2011).

Around the world, traders in the currency market are constantly connected to each other. Decision-making about buying and selling in this market depends on several effective factors that cause the high risk in it and make it a sensitive job (Amiri et al., 2010). Therefore, it is crucial to study currency trading markets and learn about their movements to be able to generate wealth by avoiding financial losses and making financial gains (Nassirtoussi, Aghabozorgi, Wah \& Chek Ling Ngo, 2014).

Accessibility of the forex market and the opportunity to make a profit are very attractive for all users. New providers that also offer education in currency trading or foreign exchange are being established daily. They offer learning, providing the latest necessary information about trading to users. Constant learning in the field of forex means there is less room for errors and greater opportunity for success in the currency trading market. Knowledge gained by studying currency trading improves understanding of the structure of the forex market.

The development of information and communication technology has drastically changed currency trading. Other studies have found strong relations between the usage of technology-enhanced learning tools and organizational change (Čudanov, Savoiu \& Jasko, 2012). For many years, currency trading has been in the domain of banks and financial institutions. However, information technology and software tools adjusted for ease of work in the field of forex have enabled currency trading to engage both companies and individuals. Increasing the number of providers and users of forex has resulted in increased competitive struggle in the field of acquiring customers and users. Companies that deal with foreign exchange trading use different means. In addition to marketing, many companies that deal with foreign exchange trading increasingly use the strategy of providing education as a method of customer acquisition. It is necessary to understand the interest of potential customers and existing users for learning in the field of forex to see which kind of learning best suits them. In recent years, the popularity of currency trading has been increasing intensely (Pintar, 2013). This is in parallel with the growing number of users participating in the forex market and with higher demand for learning in this field.

A perfect education strategy for learning about currency trading does not exist. A large number of different users have a high number of individual learning needs and styles. According to Pintar, Jereb, Vukovič and Urh (2015), information on websites that offer education in the field of foreign exchange could be using adaptive learning, which is adapted to the individual's needs. Users have to be continually informed about innovations in foreign exchange trading and are therefore using different learning approaches. Trends in educational processes are aimed at technological development and rapid transmission of information. We have determined that people are interested in learning in the field of currency trading. Moreover, the online learning of forex is most common among users, but we cannot totally ignore the personal (auditory teaching) approach. Through the research and literature review, we wanted to answer the following research questions (RQ):

RQ1: In what kind of learning in the field of currency trading are people interested? Moreover, are there any differences in the interest in learning regarding gender, age, and education level?

RQ2: What would motivate them for learning in the field of currency trading? Moreover, do people with financial credit have different motivation factors compared to those who do not have credit?

In the next section, the methodology and results of the research of interest in learning in the field of currency trading are presented. 


\section{Methodology}

\subsection{Instrument}

We gathered the data through an online questionnaire. The questionnaire contained 55 questions relating to 1) data of the respondent (age, gender, credit, working status, relationship status and education), and 2) factors relating interest in learning about currency trading. The questionnaire was of the closed type. All statements of the interest in the type of currency trading learning were measured on the 5-point Likert-type scale of presence, in which »1« means »very low $\ll$ and $» 5 \ll$ means »very high $«$.

To answer all the research questions, the overall reliability of the questionnaire with Cronbach's alpha reliability test was first tested; shown in Table 1, these tests were made for three segments of the questionnaire involving people's interest in the type of learning in the field of currency trading, which types would motivate and discourage them from learning about currency trading, and the importance of learning elements for learning forex online.

Table 1: Cronbach's alpha test of four questionnaire segments

\begin{tabular}{|l|c|c|c|}
\hline $\begin{array}{l}\text { Questionnaire } \\
\text { segments }\end{array}$ & $\begin{array}{c}\text { Cronbach's } \\
\text { alpha }\end{array}$ & $\begin{array}{c}\text { Cronbach's } \\
\text { alpha based } \\
\text { on standard- } \\
\text { ized items }\end{array}$ & $\begin{array}{c}\text { No. of } \\
\text { items }\end{array}$ \\
\hline $\begin{array}{l}\text { Evaluated } \\
\text { Interest in the } \\
\text { type of learning } \\
\text { in the field of } \\
\text { currency trading }\end{array}$ & 0.881 & 0.884 & 8 \\
\hline $\begin{array}{l}\text { Evaluated moti- } \\
\text { vation factors for } \\
\text { learning in cur- } \\
\text { rency trading }\end{array}$ & 0.963 & 0.963 & 9 \\
\hline
\end{tabular}

Table 1 presents the Cronbach alpha values based on standardized items for all three segments of the questionnaire used in this research. The values are all calculated higher than 0.7; this means that they are acceptable values and that the scale used in our questionnaire is reliable (see Tabachnick and Fidell, 2007).

\subsection{Sample}

The survey was performed in spring 2015 in Slovenia among unsystematically contacted respondents. The questionnaire was randomly sent and delivered in an electronic form, structured in the $1 \mathrm{ka}$ online program (https://www.1 ka.si). A total of 107 questionnaires were completed fully and properly. The sample consists of 107 people, 54\% were female, and $46 \%$ were male. The respondents were aged between
20 and 76 years (mean: 32 years and 10 months), 51\% were younger than 30 years old, and $49 \%$ were aged 30 years or older; $80 \%$ of respondents did not have credit, and $20 \%$ had a credit; $30 \%$ of the people questioned were single (never married), $44 \%$ were in a relationship (unmarried), $23 \%$ were married, $1 \%$ were widows and $2 \%$ are divorced. According to their working status, $43 \%$ were permanently employed for an indefinite period, $14 \%$ were temporarily employed for a limited time, $13 \%$ were currently unemployed, $29 \%$ were students, and $1 \%$ were pensioners who had already retired. Education among respondents was classified with hierarchical clustering into three groups: group one $(31 \%)$ consists of people who finished elementary school, high school, and vocational school; group two includes respondents that had finished their bachelor's degree (43\%); the most educated group had a master's or doctoral degree (26\%) (Table 2).

Table 2: Demographic data

\begin{tabular}{|l|c|r|}
\hline \multirow{3}{*}{ Gender } & male & $46 \%$ \\
\cline { 2 - 3 } Age & female & $54 \%$ \\
\hline \multirow{4}{*}{ Have credit } & up to 29 & $51 \%$ \\
\cline { 2 - 3 } & 30 or more & $49 \%$ \\
\hline \multirow{4}{*}{ Status } & yes & $20 \%$ \\
\cline { 2 - 3 } & no & $80 \%$ \\
\cline { 2 - 3 } & single & $30 \%$ \\
\cline { 2 - 3 } & in a relationship & $44 \%$ \\
\cline { 2 - 3 } & married & $23 \%$ \\
\cline { 2 - 3 } & widowed & $1 \%$ \\
\hline \multirow{4}{*}{ Working status } & divorced & $2 \%$ \\
\cline { 2 - 3 } & permanently employed & $43 \%$ \\
\cline { 2 - 3 } & temporary employed & $14 \%$ \\
\cline { 2 - 3 } & unemployed & $13 \%$ \\
\cline { 2 - 3 } & student & $29 \%$ \\
\hline \multirow{4}{*}{ Education } & pensioner & $1 \%$ \\
\cline { 2 - 3 } & elementary, high or vocational & $31 \%$ \\
\cline { 2 - 3 } & bachelor & $43 \%$ \\
\cline { 2 - 3 } & doctoral & $26 \%$ \\
\hline
\end{tabular}

The results of this study can be generalized to the population of interest in the area of Slovenia, with the proposition that the random sending of the questionnaire resulted in a random sample of participants. A sociodemographic descriptive statistical analysis of the sample supports that proposition since there is no observable deviation in the gender, age, or educational distributions within the sample. Furthermore, but with less reliable external validity (Calder, Phillips and Tybout 1982), the results are expected to be applicable in the context of developed countries that have successfully passed through economic and 
political transition in recent past like Poland, Hungary, the Czech Republic, Estonia, Chile, Uruguay, Taiwan, Slovakia, Romania, Bulgaria, Mexico, Brazil, Ghana, the Philippines, South Korea, as well as, due to recent development, countries from the former "gray zone«, such as Serbia and Croatia (Carothers, 2002).

\subsection{Data analysis}

Data gathered from the survey were first analysed with hierarchical clustering in order to determine different groups of respondents according to their age (two groups) and education (three groups). The clustering was made with Ward's method and standardized variables. For further analysis we, therefore, obtained two groups regarding their age (Group 1: $>=30$ years old; Group 2: $<30$ years old) and three groups regarding their current educational status (Group 1: elementary school, high school and vocational school; Group 2: bachelor's degree; Group 3: master's and doctoral degree).

Furthermore, we analysed descriptive statistics for the age, sex, credit, working status, relationship status and education level of respondents. In the next step, we also made descriptive statistics for three segments of the questionnaire (Table 3 and Table 4). Further analyses were made with t-test, paired samples test, a test of homogeneity of variances, and ANOVA.

\section{Results}

\subsection{Descriptive statistics}

In the following section, descriptive statistics are presented. In Table 3, descriptive statistics for interest in eight different types of learning in the field of currency trading is shown. People showed the most interest in e-learning method for currency trading learning $(\overline{\mathrm{x}}=2.50)$, followed by individual

Table 3: Descriptive statistics of interest in the type of learning in the field of currency trading $(n=107)$

\begin{tabular}{|l|c|c|}
\hline $\begin{array}{l}\text { Interest in the type of learning } \\
\text { in the field of currency trading }\end{array}$ & Mean & $\begin{array}{c}\text { Std. } \\
\text { Deviation }\end{array}$ \\
\hline individual personal consulting & $\mathbf{2 . 4 9}$ & 1.160 \\
\hline auditory learning in a group & 2.20 & 1.013 \\
\hline books and magazines & 2.39 & 1.147 \\
\hline e-learning & $\mathbf{2 . 5 0}$ & 1.152 \\
\hline conferences & 2.21 & 1.172 \\
\hline tele-conferences & 1.69 & 0.840 \\
\hline e-mail learning & 2.07 & 0.974 \\
\hline learning through social networks & $\mathbf{2 . 2 5}$ & 1.091 \\
\hline
\end{tabular}

personal consulting $(\overline{\mathrm{x}}=2.49)$, books and magazines $(\overline{\mathrm{x}}=$ $2.39)$, social networks $(\overline{\mathrm{x}}=2.25)$, conferences $(\overline{\mathrm{x}}=2.21)$, auditory learning in a group $(\overline{\mathrm{x}}=2.20)$, e-mail learning $(\overline{\mathrm{x}}=$ $2.07)$, and tele-conferences $(\overline{\mathrm{x}}=1.69)$.

Table 4 presents descriptive statistics for nine different motivation factors for learning in the field of currency trading. People would be the most motivated to learn about currency trading if they would have had information regarding the risk of trading in forex $(\overline{\mathrm{x}}=3.28)$. A recommendation from friends would motivate them $(\overline{\mathrm{x}}=3.00)$ a bit more strongly than having favourable trading terms $(\overline{\mathrm{x}}=2.98)$ and if the education or training would be free of charge $(\overline{\mathrm{x}}$ $=2.97$ ). Lower estimated motivation factors for learning in forex were the inclusion of free software for trading $(\overline{\mathrm{x}}=$ $2.87)$, the inclusion of further counselling $(\overline{\mathrm{x}}=2.83)$, access to specialised and professional literature $(\overline{\mathrm{x}}=2.79)$, the inclusion of programs and platforms with Slovenian translation $(\overline{\mathrm{x}}=2.64)$, and online learning $(\overline{\mathrm{x}}=2.54)$.

Table 4: Descriptive statistics for motivation factors for learning in the field of currency trading $(n=107)$

\begin{tabular}{|l|c|c|}
\hline $\begin{array}{l}\text { Motivation factors for learning } \\
\text { in currency trading }\end{array}$ & Mean & $\begin{array}{c}\text { Std. } \\
\text { Deviation }\end{array}$ \\
\hline free education and training & $\mathbf{2 . 9 7}$ & 1.306 \\
\hline online learning (via internet) & 2.54 & 1.200 \\
\hline $\begin{array}{l}\text { inclusion of free software for } \\
\text { trading }\end{array}$ & 2.87 & 1.304 \\
\hline inclusion of further counselling & 2.83 & 1.270 \\
\hline $\begin{array}{l}\text { given access to specialised and } \\
\text { professional literature }\end{array}$ & 2.79 & 1.259 \\
\hline $\begin{array}{l}\text { inclusion of programs and plat- } \\
\text { forms with Slovenian translation }\end{array}$ & 2.64 & 1.284 \\
\hline favourable trading terms & $\mathbf{2 . 9 8}$ & 1.296 \\
\hline recommendation of friends & $\mathbf{3 . 0 0}$ & 1.281 \\
\hline information regarding the risk & $\mathbf{3 . 2 8}$ & 1.399 \\
\hline
\end{tabular}

Table 5 presents tests of normality distribution for constructs of interest in learning, related to Research Question 1, and items comprising that construct. Kolmogorov-Smirnov tests show that none of the items fits the normal distribution, while the construct has a Sig value of 0.200 (i.e. larger than 0.05 ), and the results suggest it fits the normal distribution (Lilliefors, 1967). The Shapiro-Wilk test, which is more appropriate for smaller samples (Shapiro \& Wilk 1965), confirms the results except for the last column, so the Q-Q plot, a commonly used and effective diagnostic tool for checking normality of the data (Razali \& Wah, 2011) was used to check the issue. Since the Q-Q plot shows only a smaller deviation at the end of the spectrum, which can be treated as an outlier, a normal distribution was assumed. Furthermore, non-parametric tests were used for the items, and parametric tests were used for the constructs, as rec- 
Table 5: Analysis of distribution for items and construct of interest in learning - test of normality $(n=107)$

\begin{tabular}{|l|c|c|c|c|c|c|}
\hline \multirow{2}{*}{} & \multicolumn{3}{|c|}{ Kolmogorov-Smirnov $^{\mathbf{a}}$} & \multicolumn{3}{c|}{ Shapiro-Wilk } \\
\cline { 2 - 7 } & Statistic & df & Sig. & Statistic & df & Sig. \\
\hline individual personal consulting & 0.214 & 107 & 0.000 & 0.891 & 107 & 0.000 \\
\hline auditory learning in a group & 0.184 & 107 & 0.000 & 0.864 & 107 & 0.000 \\
\hline books and magazines & 0.185 & 107 & 0.000 & 0.888 & 107 & 0.000 \\
\hline e-learning & 0.174 & 107 & 0.000 & 0.895 & 107 & 0.000 \\
\hline conferences & 0.233 & 107 & 0.000 & 0.851 & 107 & 0.000 \\
\hline tele-conferences & 0.299 & 107 & 0.000 & 0.765 & 107 & 0.000 \\
\hline e-mail learning & 0.227 & 107 & 0.000 & 0.843 & 107 & 0.000 \\
\hline learning through social networks & 0.211 & 107 & 0.000 & 0.862 & 107 & 0.000 \\
\hline Interest in learning & $\mathbf{0 . 0 7 2}$ & $\mathbf{1 0 7}$ & $\mathbf{0 . 2 0 0}$ & $\mathbf{0 . 9 5 8}$ & $\mathbf{1 0 7}$ & $\mathbf{0 . 0 0 2}$ \\
\hline
\end{tabular}

* This is a lower bound of the true significance.

a. Lilliefors Significance Correction

ommended by Krishnaswamy, Sivakumar, and Mathirajan (2004).

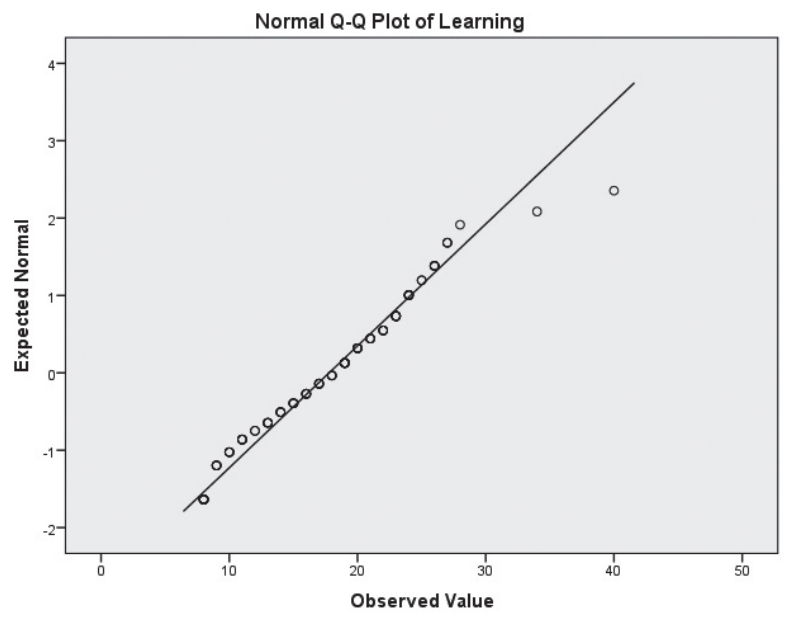

Figure 1: Q-Q plot of Interest in learning construct

Analysis of the distribution of items and constructs related to motivation for learning are presented in Table 6 . No items or the construct have significance above 0.05 , so the null hypothesis that distribution fits normal distribution is rejected for all items and for the construct. Nonparametric tests were used for the items and the construct in the further analysis.

\subsection{Analyses of research questions}

RQ1: In what kind of learning in the field of currency trading are people interested? Moreover, are there any differences in the interest in learning regarding gender, age, and education level?
To answer the first research question, a paired sample t-test for interest in the type of learning about currency trading was performed. We verified potential users' interest with the help of a statement containing eight different variables (see Table 3) assessed on a 5-point Likert scale. The results in Table 3 show that none of the average values is outstanding. The e-learning method for learning about currency trading was assessed the highest $(\overline{\mathrm{x}}=2.50)$, followed by individual personal consulting $(\overline{\mathrm{x}}=2.49)$, books and magazines $(\overline{\mathrm{x}}=2.39)$ and learning through social networks $(\overline{\mathrm{x}}=2.25)$. We tested whether the differences between the average of the variable »e-learning« and the other three variables are statistically important with a paired sample t-test.

The averages of the four variables that are related to the interest in the type of learning in the field of currency trading were compared. Seven paired Wilcoxon tests were performed with each pair of variables having their null and alternative hypothesis stated:

- variable »individual personal consulting«:

$\mathrm{H}_{0}: \mu_{\text {e-learning }}=\mu_{\text {personal consulting }}, \mathrm{H}_{1}: \mu_{\text {e-learning }}>$

$\mu_{\text {personal consulting }}$

- variable »auditory learning in a group $\ll: \mathrm{H}_{0}: \mu_{\text {e-learning }}=$ $\mu_{\text {auditory learning }}, \mathrm{H}_{1}: \mu_{\text {e-learning }}>\mu_{\text {auditory learning }}$

- variable »books and magazines $«: \mathrm{H}_{0}: \mu_{\mathrm{e}-\text { learning }}=$ $\mu_{\text {books and magazines }}, \mathrm{H}_{1}: \mu_{\text {e-learning }}>\mu_{\text {books and magazines }}$

- $\quad$ variable »conferences $\ll: \mathrm{H}_{0}: \mu_{\mathrm{e}-\text { learning }}=\mu_{\text {conferences }}$, $\mathrm{H}_{1}: \mu_{\text {e-learning }}>\mu_{\text {conferences }}$

- $\quad$ variable »tele-conferences $«: \mathrm{H}_{0}: \mu_{\text {e-learning }}=$ $\mu_{\text {tele-conferences }}, H_{1}: \mu_{\text {e-learning }}>\mu_{\text {tele-conferences }}$

- $\quad$ variable $)$ e-mail learning $\ll: \mathrm{H}_{0}: \mu_{\mathrm{e}-\text { learning }}=\mu_{\mathrm{e} \text {-mail }}$, $\mathrm{H}_{1}: \mu_{\text {e-learning }}>\mu_{\mathrm{e} \text {-mail }}$

- variable »learning through social networks «:

$\mathrm{H}_{0}: \mu_{\text {e-learning }}=\mu_{\text {social networks }}, \mathrm{H}_{1}: \mu_{\text {e-learning }}>$

$\mu_{\text {social networks }}$ 
Table 6: Analysis of distribution for items and construct of motivation for learning - tests of normality ( $n=107)$

\begin{tabular}{|l|c|c|c|c|c|c|}
\hline \multirow{2}{*}{} & \multicolumn{3}{|c|}{ Kolmogorov-Smirnov $^{\mathbf{a}}$} & \multicolumn{3}{c|}{ Shapiro-Wilk } \\
\cline { 2 - 7 } & Statistic & df & Sig. & Statistic & df & Sig. \\
\hline free education and training & 0.205 & 107 & 0.000 & 0.893 & 107 & 0.000 \\
\hline online learning (via internet) & 0.200 & 107 & 0.000 & 0.880 & 107 & 0.000 \\
\hline inclusion of free software for trading & 0.172 & 107 & 0.000 & 0.896 & 107 & 0.000 \\
\hline inclusion of further counselling & 0.179 & 107 & 0.000 & 0.889 & 107 & 0.000 \\
\hline $\begin{array}{l}\text { given access to specialised and profes- } \\
\text { sional literature }\end{array}$ & 0.169 & 107 & 0.000 & 0.897 & 107 & 0.000 \\
\hline $\begin{array}{l}\text { inclusion of programs and platforms with } \\
\text { Slovenian translation }\end{array}$ & 0.160 & 107 & 0.000 & 0.891 & 107 & 0.000 \\
\hline favourable trading terms & 0.186 & 107 & 0.000 & 0.893 & 107 & 0.000 \\
\hline recommendation of friends & 0.156 & 107 & 0.000 & 0.909 & 107 & 0.000 \\
\hline information regarding the risk & 0.210 & 107 & 0.000 & 0.876 & 107 & 0.000 \\
\hline Motivation & 0.124 & 107 & 0.000 & 0.917 & 107 & 0.000 \\
\hline
\end{tabular}

a. Lilliefors Significance Correction

The results of the Wilcoxon test are shown in Table 7. For the first pair, e-learning-individual personal consulting, the $t$-value is -0.095 and the p-value is 0.925 . For the third pair, e-learning-books and magazines, the t-value is -0.957 and the p-value is 0.339 . For all the other pairs, the twotailed asymptotic significance is less than 0.05 . On the basis of these results $(\mathrm{p}<0.05)$, there are no significant differences in measures of centrality between »e-learning « and the other two variables (individual personal consulting, books and magazines). We can conclude that potential users of learning in currency trading are equally interested in e-learning, individual personal consulting, as well as books and magazines. However, all the other pairs have statistically significant differences in the average, which can be confirmed at the $5 \%$ significance level. Further analysis of averages for all eight items, as well as ranks calculated in the Wilcoxon test, directs us toward confirming $\mathrm{H} 1$ in cases of auditory learning in a group; conferences; tele-conferences and e-mail learning, i.e. potential users of learning in currency trading are more interested in e-learning than in learning through any one of those methods.

Furthermore, a t-test was used to determine whether there are any differences in the interest in learning regarding gender. We again set the null and alternative hypothesis for each variable:

$\mathrm{H}_{0}$ : Men and woen are on average not equally interested in specific learning types in the field of currency trading (individual personal consulting; auditory learning in a group; books and magazines; e-learning; conferences; tele-conferences; e-mail learning; learning through social networks).

$\mathrm{H}_{1}$ : Men and women are on average equally interested in specific learning types in the field of currency trading (individual personal consulting; auditory learning in a group; books and magazines; e-learning; conferences; tele-conferences; e-mail learning; learning through social networks).

Table 7: Paired sample Wilcoxon for interest in the type of learning in the field of currency trading

\begin{tabular}{|l|c|c|c|c|c|c|c|}
\hline & $\begin{array}{c}\text { e-learning } \\
- \text { individual } \\
\text { personal } \\
\text { consulting }\end{array}$ & $\begin{array}{c}\text { e-learning } \\
- \text { auditory } \\
\text { learning in } \\
\text { a group }\end{array}$ & $\begin{array}{c}\text { e-learning } \\
- \text { books and } \\
\text { magazines }\end{array}$ & $\begin{array}{c}\text { e-learning - } \\
\text { conferences }\end{array}$ & $\begin{array}{c}\text { e-learning - } \\
\text { tele-confer- } \\
\text { ences }\end{array}$ & $\begin{array}{c}\text { e-learning } \\
\text { - e-mail } \\
\text { learning }\end{array}$ & $\begin{array}{c}\text { e-learning } \\
- \text { learning } \\
\text { through } \\
\text { social net- } \\
\text { works }\end{array}$ \\
\hline Z & $-.095^{\mathrm{b}}$ & $-2.796^{\mathrm{b}}$ & $-0.957^{\mathrm{b}}$ & $-2.635^{\mathrm{b}}$ & $-6.460^{\mathrm{b}}$ & $-4.116^{\mathrm{b}}$ & $-2.460^{\mathrm{b}}$ \\
\hline $\begin{array}{l}\text { Asymp. Sig. } \\
\text { (2-tailed) }\end{array}$ & 0.925 & 0.005 & 0.339 & 0.008 & 0.000 & 0.000 & 0.014 \\
\hline
\end{tabular}

a. Wilcoxon Signed Ranks Test

b. Based on negative ranks. 
Table 8a: Results of Mann-Whitney U test for differences between genders regarding interest in the specific learning type in the field of currency trading

\begin{tabular}{|l|c|c|c|c|c|c|c|c|}
\hline & $\begin{array}{c}\text { individual } \\
\text { personal } \\
\text { consulting }\end{array}$ & $\begin{array}{c}\text { auditory } \\
\text { learning } \\
\text { in a group }\end{array}$ & $\begin{array}{c}\text { books and } \\
\text { magazines }\end{array}$ & $\begin{array}{c}\text { e-learn- } \\
\text { ing }\end{array}$ & $\begin{array}{c}\text { confer- } \\
\text { ences }\end{array}$ & $\begin{array}{c}\text { tele-con- } \\
\text { ferences }\end{array}$ & $\begin{array}{c}\text { e-mail } \\
\text { learning }\end{array}$ & $\begin{array}{c}\text { learning } \\
\text { through } \\
\text { social net- } \\
\text { works }\end{array}$ \\
\hline $\begin{array}{l}\text { Mann- } \\
\text { Whitney U }\end{array}$ & 1342.500 & 1260.500 & 1397.500 & 1386.500 & 1398.000 & 1373.500 & 1256.000 & 1356.000 \\
\hline Wilcoxon W & 3053.500 & 2485.500 & 3108.500 & 3097.500 & 3109.000 & 2598.500 & 2481.000 & 2581.000 \\
\hline Z & -0.507 & -1.051 & -0.152 & -0.223 & -0.150 & -0.326 & -1.086 & -0.425 \\
\hline $\begin{array}{l}\text { Asymp. Sig. } \\
\text { (2-tailed) }\end{array}$ & 0.612 & 0.293 & 0.879 & 0.823 & 0.881 & 0.745 & 0.277 & 0.671 \\
\hline
\end{tabular}

a. Grouping Variable: Gender

Table 8a shows the results of the Mann-Whitney U, Wilcoxon $\mathrm{W}$ and $\mathrm{Z}$ tests for differences between genders regarding interest in the specific learning type in currency trading. Significance values for all test are the same, and we can conclude that there is no difference in the median value for any of the eight observed factors because all significances are valued $\mathrm{p}>0.05$.

Furthermore, a t-test has been used to analyse whether any differences exist between genders regarding the interest in learning construct. Results are given in Table $8 \mathrm{~b}$. Based on the results of Levene's test for equality of variances we cannot reject the null hypothesis of equality of variances at the $5 \%$ significance level, because the F-value is 0.286 with the significance of 0.594 . Based on the results of t-tests, the null hypothesis of equality of means cannot be rejected at the $5 \%$ significance level (as $\mathrm{p}$ is 0.916 ). On the basis of the information received, there are no differences between genders regarding interest in the type of learning in the field of currency trading, nor for the general construct interest in learning.

Next, a t-test was used to determine whether there are any differences in the interest in learning regarding age. Data gathered from the survey were already analysed with hierarchical clustering; therefore, there are two groups according to age (Group 1: $>=30$ years old; Group 2: $<30$ years old). In Group 1, there are 52 respondents; in Group 2, there are 55 respondents. We again set the null and alternative hypothesis for each variable:
$\mathrm{H}_{0}$ : People younger than 30 years and people that are 30 years old and older are, on average, not equally interested in learning (individual personal consulting; auditory learning in a group; books and magazines; e-learning; conferences; tele-conferences; e-mail learning; learning through social networks) in currency trading.

$\mathrm{H}_{1}$ : People younger than 30 years and people that are 30 years old and older are, on average, equally interested in learning (individual personal consulting; auditory learning in a group; books and magazines; e-learning; conferences; tele-conferences; e-mail learning; learning through social networks) in currency trading.

Table 9a shows the results of Mann-Whitney U-tests with groups according to age, regarding interest in the type of learning in the field of currency trading. Based on the significance values, we can conclude that differences do not exist in the categories of individual personal consulting; books and magazines; e-learning; e-mail learning and tele-conferences. Participants have ranked $(\mathrm{p}<0.05)$ : auditory learning in a group; conferences and learning through social networks significantly differently. As expected, the ranks are higher for the group of younger participants, below the age of 30 , who show more interest in these types of learning in the field of currency trading learning, than older people.

Table 8b: Results of t- test for differences between genders regarding interest for learning in the field of currency trading

\begin{tabular}{|l|c|c|c|c|c|}
\hline \multirow{2}{*}{$\begin{array}{l}\text { Interest in learning in } \\
\text { the field of currency trading }\end{array}$} & \multicolumn{2}{|c|}{ Levene's test for equality of variances } & \multicolumn{3}{|c|}{ T-test for equality of means } \\
\cline { 2 - 6 } & F & Sig. & t & df & $\begin{array}{c}\text { p. } \\
\text { (2-tailed) }\end{array}$ \\
\hline Values & 0.286 & 0.594 & -0.105 & 105 & 0.916 \\
\hline
\end{tabular}


Table 9a: Results of Mann-Whitney U test for differences between ages regarding interest in for the type of learning in the field of currency trading

\begin{tabular}{|l|c|c|c|c|c|c|c|c|}
\hline & $\begin{array}{c}\text { individual } \\
\text { personal } \\
\text { consult- } \\
\text { ing }\end{array}$ & $\begin{array}{c}\text { auditory } \\
\text { learn- } \\
\text { ing in a } \\
\text { group }\end{array}$ & $\begin{array}{c}\text { books } \\
\text { and mag- } \\
\text { azines }\end{array}$ & $\begin{array}{c}\text { e-learn- } \\
\text { ing }\end{array}$ & conferences & $\begin{array}{c}\text { tele-confer- } \\
\text { ences }\end{array}$ & $\begin{array}{c}\text { e-mail } \\
\text { learning }\end{array}$ & $\begin{array}{c}\text { learning } \\
\text { through } \\
\text { social net- } \\
\text { works }\end{array}$ \\
\hline $\begin{array}{l}\text { Mann- } \\
\text { Whitney U }\end{array}$ & 1133.000 & 1009.500 & 1216.500 & 1209.500 & 1056.000 & 1240.000 & 1151.000 & 890.500 \\
\hline $\begin{array}{l}\text { Wilcoxon } \\
\text { W }\end{array}$ & 2511.000 & 2387.500 & 2594.500 & 2587.500 & 2434.000 & 2618.000 & 2529.000 & 2268.500 \\
\hline Z & -1.912 & -2.745 & -1.377 & -1.423 & -2.431 & -1.299 & -1.831 & -3.514 \\
\hline $\begin{array}{l}\text { Asymp. } \\
\text { Sig. } \\
\text { (2-tailed) }\end{array}$ & 0.056 & 0.006 & 0.169 & 0.155 & 0.015 & 0.194 & 0.067 & 0.000 \\
\hline
\end{tabular}

a. Grouping Variable: Age30

Table $9 \mathrm{~b}$ shows analysis for the general, construct variable interest in learning. Based on the results of Levene's test for equality of variances we cannot reject the hypothesis of equality of variances at the $5 \%$ significance level. Based on the t-tests, we can conclude that there are significant differences in interest in learning in the field of currency trading among people who are younger than 30 years and those who are 30 years old and older.

Furthermore, a Kruskal-Wallis Test was used to determine if there are any differences in the interest in learning method regarding education level. In Group 1 are included respondents with elementary school; in Group 2 are included respondents with high or vocational school; in Group 3 are included respondents with a university degree. We again set the null and alternative hypothesis for each variable:

$\mathrm{H}_{0}$ : There are no statistically significant differences between the educational levels of their interest in learning (individual personal consulting; auditory learning in a group; books and magazines; e-learning; conferences; tele-conferences; e-mail learning; learning through social networks) in the field of currency trading.

$\mathrm{H}_{1}$ : There are statistically significant differences between the educational levels of their interest in learning (individual personal consulting; auditory learning in a group; books and magazines; e-learning; conferences; tele-conferences; e-mail learning; learning through social networks) in the field of currency trading.
The results in Table 10 show the results of the p-values as being higher than 0.05 for all variables; therefore, we can conclude that statistically significant differences between the three groups do not exist at a 5\% significance level. ANOVA analysis for the constructed variable yielded the same result, i.e. that there were no differences between the groups according to educational levels. Therefore, regardless of their level of education, all respondents are equally interested in all types of learning in the field of currency trading and in learning in general.

RQ2: What would motivate them for learning in the field of currency trading? Moreover, do people with financial credit have different motivation factors compared to those who do not have credit?

In order to answer the second research question, a paired sample t-test for motivation factors of learning in the field of currency trading was performed. We verified potential users' motivation with the help of a statement containing nine different variables (see Table 3), assessed on a five-point Likert scale. The results in Table 3 show that none of the average values is outstanding. People on average assessed that information regarding the risk would motivate them the most for learning in the field of currency trading $(\overline{\mathrm{x}}=3.28)$, followed by recommendation of friends $(\overline{\mathrm{x}}=$ $3.00)$, favourable trading terms $(\overline{\mathrm{x}}=2.98)$ and free education and training $(\overline{\mathrm{x}}=2.97)$. We tested whether the differences between the average of variable »information regarding the

Table 9b: Results of t-test for differences between ages regarding general for the type of learning in the field of currency trading

\begin{tabular}{|l|c|c|c|c|c|}
\hline \multirow{2}{*}{$\begin{array}{l}\text { Interest in learning in the } \\
\text { field of currency trading }\end{array}$} & \multicolumn{2}{|c|}{ Levene's test for equality of variances } & \multicolumn{3}{|c|}{ T-test for equality of means } \\
\cline { 2 - 6 } & $\mathbf{F}$ & Sig. & $\mathbf{t}$ & $\mathbf{d f}$ & p. (2-tailed) \\
\hline & 0.052 & 0.821 & 2.961 & 105 & 0.0004 \\
\hline
\end{tabular}


Table 10: Results of the Kruskal-Wallis Test for differences between educational levels in their interest in learning in the field of currency trading

\begin{tabular}{|l|c|c|c|c|c|c|c|c|}
\hline & $\begin{array}{c}\text { individual } \\
\text { personal } \\
\text { consulting }\end{array}$ & $\begin{array}{c}\text { auditory } \\
\text { learning } \\
\text { in a group }\end{array}$ & $\begin{array}{c}\text { books and } \\
\text { magazines }\end{array}$ & e-learning & conferences & $\begin{array}{c}\text { tele-con- } \\
\text { ferences }\end{array}$ & $\begin{array}{c}\text { e-mail } \\
\text { learning }\end{array}$ & $\begin{array}{c}\text { learning } \\
\text { through } \\
\text { social net- } \\
\text { works }\end{array}$ \\
\hline Chi-Square & 1.907 & 0.562 & 0.199 & 0.041 & 0.047 & 0.361 & 1.111 & 1.632 \\
\hline df & 2 & 2 & 2 & 2 & 2 & 2 & 2 & 2 \\
\hline Asymp. Sig. & 0.385 & 0.755 & 0.905 & 0.980 & 0.977 & 0.835 & 0.574 & 0.442 \\
\hline
\end{tabular}

risk « and other three variables are statistically significant with a paired sample t-test.

The averages of the four variables that are related to the motivation factors for learning in the type of currency trading were compared. Three paired tests were performed with each pair of variables, having their null and alternative hypothesis stated:

- $\quad$ variable »recommendation of friends $\ll$ :

$$
\begin{aligned}
& \mathrm{H}_{0}: \mu_{\text {information }}=\mu_{\text {recommendation }}, \\
& \mathrm{H}_{1}: \mu_{\text {information }}>\mu_{\text {recommendation }}
\end{aligned}
$$

- $\quad$ variable $»$ favourable trading terms $«: \mathrm{H}_{0}: \mu_{\text {information }}=$ $\mu_{\text {trading terms }}, \mathrm{H}_{1}: \mu_{\text {information }}>\mu_{\text {trading terms }}$

- variable »free education and training $«: \mathrm{H}_{0}: \mu_{\text {information }}=$ $\mu_{\text {free education }}, \mathrm{H}_{1}: \mu_{\text {information }}>\mu_{\text {free education }}$

The results of paired sample Wilcoxon tests are shown in Table 11. For all three pairs, p-values are lower than 0.05 , which means that the average of the variable »information regarding the risk « has a different rank from the average of all other variables at a 5\% significance level. Analysis of the ranks show higher ranks for information regarding the risk variable, and we can conclude that respondents would be most motivated for learning in the field of currency trading if they obtained and possessed accurate information regarding the risk.

Furthermore, a Mann-Whitney U test was used to determine if there are any differences in the motivation factors in learning among people with financial credit and those who do not have credit. We set the null and alternative hypothesis for each variable:

$\mathrm{H}_{0}$ : People with financial credit and people without financial credit are, on average, equally motivated by motivation factors (free education and training; online learning; inclusion of free software for training; inclusion of further counselling; given access to specialised and professional literature; inclusion of programs and platforms with Slovenian translation; favourable trading terms; recommendation of friends; information regarding the risk) for learning in the field of currency trading.

$\mathrm{H}_{1}$ : People without financial credit are, on average, more motivated by motivation factors (free education and training; online learning; inclusion of free software for training; inclusion of further counselling; given access to specialised and professional literature; inclusion of programs and platforms with Slovenian translation; favourable trading terms; recommendation of friends; information regarding the risk) for learning in the field of currency trading, than people with financial credit.

Table 12 shows the results of the Mann-Whitney test for these variables; because $P$ values are larger than 0.05 for all three observed statistics, we can conclude that there are no differences between respondents who have credit and respondents who do not have credit.

Table 11: Wilcoxon Signed Ranks Test for motivation factors for learning in the field of currency trading

\begin{tabular}{|l|c|c|c|}
\hline & $\begin{array}{c}\text { information regarding the risk- } \\
\text { recommendation of friends }\end{array}$ & $\begin{array}{c}\text { information regarding the risk } \\
\text { - favourable trading terms }\end{array}$ & $\begin{array}{c}\text { information regarding the risk - } \\
\text { free education and training }\end{array}$ \\
\hline $\mathrm{Z}$ & $-3.192^{\mathrm{b}}$ & $-3.846^{\mathrm{b}}$ & $-3.056^{\mathrm{b}}$ \\
\hline $\begin{array}{l}\text { Asymp. Sig. } \\
\text { (2-tailed) }\end{array}$ & 0.001 & 0.000 & 0.002 \\
\hline
\end{tabular}

a. Wilcoxon Signed Ranks Test

b. Based on negative ranks. 
Table 12: Results of the test for equality of means between people situation of having or not having a financial credit in motivation factors for learning in the field of currency trading.

Test Statistics ${ }^{\mathrm{a}}$

\begin{tabular}{|l|c|c|c|c|c|c|c|c|c|}
\hline & $\begin{array}{c}\text { free } \\
\text { educa- } \\
\text { tion and } \\
\text { training }\end{array}$ & $\begin{array}{c}\text { online } \\
\text { learn- } \\
\text { ing (via } \\
\text { internet) }\end{array}$ & $\begin{array}{c}\text { inclusion } \\
\text { of free } \\
\text { software } \\
\text { for trad- } \\
\text { ing }\end{array}$ & $\begin{array}{c}\text { inclusion } \\
\text { of further } \\
\text { counsel- } \\
\text { ling }\end{array}$ & $\begin{array}{c}\text { given } \\
\text { access to } \\
\text { special- } \\
\text { ised and } \\
\text { profes- } \\
\text { sional lit- } \\
\text { erature } \\
\text { programs } \\
\text { and plat- } \\
\text { forms } \\
\text { with } \\
\text { Slovenian } \\
\text { transla- } \\
\text { tion }\end{array}$ & $\begin{array}{c}\text { inclu- } \\
\text { favour- } \\
\text { able } \\
\text { trading } \\
\text { terms }\end{array}$ & $\begin{array}{c}\text { recom- } \\
\text { menda- } \\
\text { tion of } \\
\text { friends }\end{array}$ & $\begin{array}{c}\text { infor- } \\
\text { mation } \\
\text { regard- } \\
\text { ing the } \\
\text { risk }\end{array}$ \\
\hline $\begin{array}{l}\text { Mann- } \\
\text { Whitney } \\
\text { U }\end{array}$ & 749.500 & 783.500 & 705.000 & 802.000 & 706.000 & 786.500 & 736.000 & 702.000 & 695.000 \\
\hline $\begin{array}{l}\text { Wilcoxon } \\
\text { W }\end{array}$ & 980.500 & 1014.500 & 936.000 & 1033.000 & 937.000 & 1017.500 & 967.000 & 933.000 & 926.000 \\
\hline Z & -1.237 & -0.970 & -1.593 & -0.816 & -1.587 & -0.938 & -1.347 & -1.615 & -1.672 \\
\hline $\begin{array}{l}\text { Asymp. } \\
\text { Sig. } \\
\text { (2-tailed) }\end{array}$ & 0.216 & 0.332 & 0.111 & 0.415 & 0.113 & 0.348 & 0.178 & 0.106 & 0.094 \\
\hline
\end{tabular}

a. Grouping Variable: Financial credit

\section{Discussion and conclusion}

Interest in the type of learning about currency trading and differences in the interest in learning regarding gender, age, and education level are critical factors. On average, people assessed the e-learning method for their interest in learning in the field of currency trading the highest $(\overline{\mathrm{x}}=2.50)$. There is also high interest in learning about forex with individual personal consulting and by using books and magazines. Current trends in educational processes are aimed at technological development and the rapid transmission of information; consequently, e-learning has been proved to be preferred and popular among people, offering advantages such as geographical reach, learner control, cost effectiveness, control over students' activities, and others ( Hu \& Hui, 2012). On the basis of the analysed information, there are no differences between genders and the levels of education regarding interest in the type of learning in the field of currency trading. These results are somewhat aligned with the study of the Moodle learning management system that found that there were no differences between genders in the satisfaction with quality characteristics, but differences were found according to student's age (Horvat et al. 2013; Horvat et al. 2015). The research has indicated that people of all ages have the same interest for the type of learning about currency trading with individual personal consulting, books and magazines, e-learning, tele-conferences and with; furthermore, those people who are younger than 30 years $(<30$ years) value the types of learning including individual auditory learning in a group, conferences and learning through social networks more, and are therefore more interested in these types of learning about currency trading learning than older people ( $>=30$ years) are.

The results of the research show that people would be most motivated for learning about currency trading if they retrieved and possessed the right information regarding risks. Retrieving this information is a highly sophisticated process, which is a combination of current information, macro-economic indicators and the situation on the currency market. Trading in forex, with its high potential profitability, is essentially risky (Amiri et al., 2010). Furthermore, there are no differences between credit holders and people with no credit with regard to the factors of free education and training, online learning, the inclusion of further counselling, access to specialized and professional literature, the inclusion of programs and platforms with Slovenian translation and favorable trading terms. For the other factors (inclusion of free software for trading, recommendation of friends, information regarding the risk), the results show that people who do not have financial credit value these variables more and are, therefore, more motivated in these motivation factors for learning in the field of currency trading, than people who have financial credit. We must be aware that underinvesting in any form of education can have consequences in many aspects, but in many cases having credit means that 
there are fewer funds to be spent on the education of an individual (Del Rey and Estevan, 2013).

People are most discouraged about learning about currency trading because of their fear of having the lack of prior knowledge. The results also show that people regardless of their working status (unemployed, students, temporary employed, permanently employed) are furthermore equally discouraged by the factors of lack of time, family, and lack of funds. Differences exist in the evaluation of the discouraging factor for learning in the currency trading $» j o b \ll$ where this factor discourages the most those people who are permanently employed. Furthermore, the results show that people (single, in a relationship, married) are equally discouraged by factors of lack of time, job, lack of funds, and lack of prior knowledge, regardless of their relationship status. We can conclude that the differences exist in the evaluation of the »family« discouraging factor for learning in currency trading, where this factor discourages the most those people who are married.

This study has its limitations and weaknesses. For further data capture and processing, we should aim to gain more answers from respondents to obtain a greater sample. Another disadvantage of the research is the recognition and general reputation of forex. The providers of education in currency trading should first consider assuring learners' satisfaction in order to improve the popularity of currency trading. When focusing on the aspects of learning about currency trading in the future, e-learning is the obvious solution for rapid expansion. Such learning requires much focus and attention; therefore, motivation is essential.

Together, the results show that the interest in educating and learning in the field of currency trading among people exists; however, many possibilities to increase this interest remain. Further research should be focused towards expected increases in the number of potential users of currency trading, and if the requirements will be provided for the relevant learning. Due to the extremely rapid development of technology and the rapidly changing information affecting the currency market, it is necessary to improve the existing trends of the educational processes in forex. With great potential for learning, education in this field should focus in the direction of the development of new applications and programs. The methods and techniques of education that are now accessible to users are often unattractive and uninteresting; therefore, they should be simplified, in particular through the development of a software trading platform that would allow faster understanding of currency trading. For the users interested in trading in the forex market, it is important to reduce the costs of learning. In order to become successful and effective traders, beginners in particular should not underestimate the importance of education. Constant learning in the field of currency trading contributes significantly to positive outcomes and is too often disregarded.

\section{Literature}

Amiri, M., Zandieh, M., Vahdani B., Soltani, R., \& Roshanaei, V. (2010). An integrated eigenvector-DEA-TOPSIS methodology for portfolio risk evaluationin the FOREX spot market. Expert Systems with Applications, 37, 509-516, http://dx.doi. org/10.1016/j.eswa.2009.05.041

Calder, B. J., Phillips, L. W. \& Tybout, A. M. (1982). The concept of external validity. Journal of Consumer Research, 9(1), pp.240-244, http://dx.doi.org/10.1086/208920

Carothers, T. (2002). The end of the transition paradigm. Journal of Democracy, 13(1), 5-21, http://dx.doi.org/10.1353/jod. 2002.0003

Chau, F., Deesomsak, R., \& Lau, M. C. K. (2011). Investor sentiment and feedback trading: Evidence from the exchange-traded fund markets. International Review of Financial Analysis, 23(5), 292-305, http://dx.doi.org/10.1016/j.irfa.2011.06.006

Čudanov, M., Savoiu, G., \& Jasko, O. (2012). Usage of technology enhanced learning tools and organizational change perception. Computer Science and Information Systems, 9(1), 285-302.

Del Rey, E., \& Estevan, F. (2013). Conditional cash transfers and education quality in the presence of credit constraints. Economics of Education Review, 34, 76-84, Kink.

Dempster, M. A. H., Payne, T. W., Romahi, Y. \& Thompson, G. W. P. (2001). Computational learning techniques for intraday FX trading using popular technical indicators, Neural Networks, IEEE Transactions on. 12(4). 744-754, http:// dx.doi.org/10.1109/72.935088

Evans, C., Pappas, P., \& Xhafa, F. (2013). Utilizing artificial neural networks and genetic algorithms to build an algotrading model for intra-day foreign exchange speculation. Mathematical and Computer Modelling, 58(5-6), 1249-1266, http://dx.doi.org/10.1016/j.mcm.2013.02.002

Horvat, A., Krsmanović, M., Dobrota, M., \& Čudanov, M. (2013). StudentsTrust in Distance Learning: Changes in Satisfaction and Significance. Management - Journal for management theory and practice, 16(69), 47-54.

Horvat, A., Dobrota, M., Krsmanovic, M., \& Čudanov, M. (2015). Student perception of Moodle learning management system: a satisfaction and significance analysis. Interactive Learning Environments, 23(4), 515-527.

Høidal Bjønnes, G., \& Rime, D. (2005). Dealer behavior and trading systems in foreign exchange markets. Journal of Financial Economics, 75(3), 571-605, http://dx.doi.org/10.1016/j.jfineco.2004.08.001

Hu, P. J. H., \& Hui, W. (2012). Examining the role of learning engagement in technology-mediated learning and its effects on learning effectiveness and satisfaction. Decision Support Systems, 53, 782-792, http://dx.doi.org/10.1016/j. dss.2012.05.014

Kumar, R. (2014). Strategies of Banks and Other Financial Institutions: Theories and Cases. United States: Elsevier Science Publishing Co Inc., 125-164, http://dx.doi.org/ 10.1016/B978-0-12-416997-5.00001-4

Krishnaswamy, K. N., Sivakumar, A. I., \& Mathirajan, M. (2004). Management Research Methodology: Integration of Principles. Methods and Techniques, New Delhi, India: Dorling Kindersley Ltd.

Lallouache, M., \& Abergel, F. (2014). Tick size reduction and price clustering in a FX order book. Physica A, 416, 488-498. 
Lilliefors, H. W. (1967). On the Kolmogorov-Smirnov test for normality with mean and variance unknown. Journal of the American Statistical Association, 62(318), 399-402.

Loginov, A., \& Heywood, M. I. (2013). On the Utility of Trading Criteria Based Retraining in Forex Markets. Applications of Evolutionary Computation: Lecture Notes in Computer Science, 7835, 192-202.

Nassirtoussi, A. K., Aghabozorgi, S., Wah, T. Y., \& Chek Ling Ngo, D. (2014). Text mining for market prediction: A systematic review. Expert Systems with Applications, 41, 7653-7670, http://dx.doi.org/10.1016/j.eswa.2014.06.009

Pintar, R. (2013). Development of Information System for simplification of Foreign exchange value trading. Smart organization: high potentials, lean organization, internet of things; 32nd International Conference on Organizational Science Development. Kranj: Moderna organizacija, 827-835.

Pintar, R., Jereb, E., Vukovič, G. \& Urh, M. (2015) Analysis of Web Sites for e-Learning in the Field of Foreign Exchange Trading, Procedia - Social and Behavioral Sciences, 197, 245-254, http://10.1016/j.sbspro.2015.07.131

Proano, C. R. (2011). Exchange rate determination, macroeconomic dynamics and stability under heterogeneous behavioral FX expectations. Journal of Ecomic Behavior \& Organization, 77, 177-188, http://dx.doi.org/10.1016/j.jebo.2010.10.005

Razali, N. M., \& Wah, Y. B. (2011). Power comparisons of ShapiroWilk, Kolmogorov-Smirnov, Lilliefors and Anderson-Darling tests. Journal of Statistical Modeling and Analytics, 2(1), 21-33.

Shapiro, S. S., \& Wilk, M. B. (1965). An Analysis of Variance Test for Normality (Complete Samples). Biometrika, 52(3/4), pp. 591-611.

Tabachnick, B. G., \& Fidell, L. S. (2007). Using multivariate statistics (5 ${ }^{\text {th }}$ ed.). Boston: Allyn \& Bacon.

Talebi, H., Winsor, H., \& Gavrilova, M. L. (2014). Multi-Scale Foreign Exchange Rates Ensemble for Classification of Trends in Forex Market. Procedia Computer Science, 29, 2065-2075, http://dx.doi.org/10.1016/j.procs.2014.05.190
Rok Pintar (M.Sc.) is a Doctoral student at the Faculty of Organizational Sciences, University of Maribor. His research activities are focused on education, human resource management, the implementation of e-learning, marketing, entrepreneurship, foreign exchange trading and economics. He has published several scientific papers in the aforementioned fields and is also an active participant in domestic and international conferences.

Eva Jereb is a professor in the Department of Personnel and Information Sciences and Vice Dean for Educational activity at the Faculty of Organisational Sciences, University of Maribor, Slovenia. Her main research interests are in higher education, e-learning, human resource development, personnel expert systems, self-management and telework.

Mladen Čudanov (Ph.D.) is an Assistant Professor at the Faculty of Organizational Sciences, University of Belgrade, Department for organization of business systems. He has participated in more than twenty commercial and scientific projects. His major research interests concern ICT, organization and management, restructuring business systems and organizational change management. He has published more than 80 articles in scientific journals and conference proceedings.

Marko Urh obtained his Ph.D. in the field of Organizational sciences from the University of Maribor. He is a senior lecturer in the Department of Personnel and Information Sciences at the Faculty of Organisational Sciences, University of Maribor, Slovenia. His main research interests are in higher education, e-learning, human resource development, gamification and information systems. 